\title{
The analysis of influence taken by changes in identitie's structure of South Siberia post-Soviet inhabitants over interethnic relation features
}

\begin{abstract}
When in 1990s Soviet Union disappeared, it caused post-Soviet people appeal to alternative reasons for self-consciousness growth, first of all-to an ethnic identity. This leads to definite fears that such an interest to ethnical identity can cause a interethnic tension growth. Article presented gives a subordinate analysis of ethnic and sociological researches which were held in Southern Siberia by means of formal interview from 1990 to 2016. This analysis aims to evaluate the grade of identities' transformations in region and their influence over interethnic relations features. Author comes to conclusion that changes in identity structure of region inhabitants, which took place in post-Soviet period, did not had a great influence over interethnic relations features. Tension in interethnic cooperation which could be observed in Southern Siberia (together with Russia), in his opinion, is determined by some other factors and cannot be a basis of social conflict in future.
\end{abstract}

Volume 2 Issue 6 - 2018

\begin{abstract}
Yuri MAksutin
Department of Economics and management, University of Khakassia, Russia

Correspondence: Yuri M Aksutin, Department of Economics and management, Chair of philosophy and culturology of the Institute of NF Katanov State University of Khakassia, 90 Lenin st.,Abakan,655017 Khakassia, Russia, Email aksatum@mail.ru
\end{abstract}

Received: December 17, 2017 | Published: November 26, 2018

Keywords: ethnical identity, identity, interethnic relations, conflict, contradiction

\section{Introduction}

Social and political transformations took place 25 years ago led to quality changes in the life of post-Soviet society. They cause a revision of not only social, political and economical basics, but also of whole people consciousness, that was followed by interethnic cooperation in the country in general and in its separate regions.

In 1980-1990s over ethnical Soviet identity, which united Soviet society, lost its value and finally disappeared with USSR collapse. It caused some psychological discomfort. So, appeal to ethnical identity and other traditional mechanisms of community feeling were almost inevitable. Such mechanisms enforced ethnicity factor in interethnic cooperation. So, there is a point of view according to which modern Russia takes an influence of "ethnicity and traditionalism boost" that have a great conflict potential. A wide range of Russian and foreign authors noted that social and cultural conflicts are identity conflicts which are caused by irresistible contradictions between traditional and modern outlook systems. ${ }^{1-3}$ Certain fears were voiced that ethnicity actualization (followed by incompleteness of new civil and nation state identity creation) can become a reason of social and cultural conflicts worsening. However, not everyone was agreeing to this point of view. Some researchers mentioned that it's necessary to talk about on-classical types of ethnical revival and traditionalism that are of great modernization and convergence. So, it's more appropriate to talk rather about objective and functional identity contradiction, than about conflict. ${ }^{4,5}$ In this context it is important and rather interesting to appeal to analysis of how post-Soviet Russian identities are transformed and what are their influence over interethnic cooperation. It is rather topical in such regions, where different ethnoses cooperate every day face-to-face. One of these regions is Southern Siberia. ${ }^{6}$ what is a process of Southern Siberia inhabitants' identity transformation? Does the importance of traditional values (such as ethnical one) is real, and does it really cause an escalation of interethnic conflicts? These and some coherent issues are the topic of our analysis.

\section{Example}

Starting analyzing of empirical data in region, let's take a glance on Russian trends characteristics. Researchers note that tension escalation and interethnic cooperation changes in general are result of Soviet identity creation for about 60 years that was controversial in most cases. ${ }^{3}$ This contradiction was that, in Malahov, A Vishnevskiy's opinion, "international" Soviet consciousness was in fact built on one certain ethnic, cultural and political basis-the Russian one. ${ }^{7,8}$ As a result, a new community of Soviet people with binar (Soviet/ ethnic consciousness) or even a conflict one has appeared. At the same time, Soviet identity which is based on estatism and internationalism principles did not reveal the importance of ethnic and local identities in everyday life. Soviet society and state collapse turned into small confusion for Russian population of a country that had a certain status and some time to neutralize your identity. For other nations self-consciousness was reborn by sovereignty, cultural and ethnic self-determination ideas renewal. But Russians, who almost lost ideological basis of their own consciousness (especially in regions), had to appeal to out-ethnic identities (local, Russian, regional one etc.) for strong substrate under feet. Sociological researches held in Southern Siberia about identity structure transformations in general confirm trend mentioned above. In 1990-2010s regional and republic identities were more relevant than Russian and ethnic ones. ${ }^{9,10}$ In The Republic of Khakassia in 2007, for example, Russian $(28,6 \%)$ and republican $(24,0 \%)$ identities were expressed in almost equal degree and took weaker position compared with regional-settlement identity $(33,4 \%)$. The relevance of both ethnic and cosmopolitan identity was mentioned by only $6,8 \% .{ }^{11}$ Priority of republican identity over ethnicity can be easily explained by sovereignty trend that decreased the 'Soviet ethnicity' importance. It can also be explained by the fact that in The Republic of Khakassia, for example, there were about $80,2 \%$ of Russians among the whole population. Altai and Tyva represented another data by being Russian in about $57,4 \%$ and $20,1 \%$ accordingly.

These results of regional responses are in correlation with Russian researches that display domination of Russian identity among identities of European Russia (Central and North-West regions, The Volga region, the Ural). There were from 61 till $75 \%$ of respondents. At that time, the Russian identity lost its urgency from West to 
East. There were about $51 \%$ of those who recognized themselves as Russians in Western, Eastern Siberia and Far East. ${ }^{5}$ These trends influenced interethnic situation negatively. As researchers mention, in the middle of 1990s interethnic tension of nationalism and migration processes was on the peak, but did not caused quite conflicts. ${ }^{12,13}$ In 1994-2016 interethnic relations in described region were mostly positively evaluated. In that time in the republic of Khakassia, for example, the amount of those who considered interethnic relations to be stable increased from $43 \%$ to $74 \%$; from $35 \%$ to $21 \%$ decreased the amount of respondents who mentioned some tension. But during the crisis 2005-2011 the situation turned to worse; from $74 \%$ to $42,5 \%$ went down the amount of respondents who consider interethnic relations as friendly. ${ }^{14}$ In 2005 about 18\%, and in 2011 41,5\% told about interethnic tension, and $3 \%$ and $4,5 \%$ accordingly mentioned strict interethnic tension. Both in Tyva and Altai tension de-escalation was described in 1980-1990s, after a long period of conflicts. At the beginning of 2000s Tuva displayed strengthening of positive evaluations for interethnic cooperation (36\% of Russians, $24 \%$ of Tuvinians, and $11 \%$ of negative evaluations both). ${ }^{15}$

Empirical researches of 2013-2016 held with selection proportional to amount of inhabitants revealed some different results. ${ }^{1}$ Thus, 2013 interview displayed the preponderance of Russian identity $(32,3 \%)$, the second place is taken by Republic one $(21,7 \%)$, and the third position is for the settlement identity $(15,8 \%)$. The regional (Siberian) identity yielded to settlement one and took the fourth position $(11,9 \%)$ when the ethnic one was just the fifth $(10,6 \%)$. Global identity was the sixth among other identities' hierarchy $(6,6 \%) .{ }^{16}$ We should mention that there were the Russian respondents who identified themselves with the Russian inhabitants $(37,7 \%)$. At the same time the amount of those who consider themselves to be Russians are twice less in Siberia then in western part of Russia. At about $25 \%$ Russian identity was relevant for Khakas, Tuvinian and Altay people, who displayed mostly the republic identity (Khakasses-35,5\%; Tuvinians-27,4\%; the Altay people-21,6\%). It's interesting to notice that only for $37,8 \%$ of Altay people the ethnical identity was the important feature, when for Khakasses it was only the fifth $(10 \%)$, for the Tuvinians the 4 th $(15 \%)$, and the last one for the Russians $(6,8 \%)$. The relevance of republic identity for Turkic nations and the regional (along with the settlement one) for the Russians is explained by the wide range of earlier mentioned trends such as: sovereignty and national and ethnic autonomies in 1990s or internationalization practice in Soviet time, etc.

Interethnic relations in Southern Siberia were evaluated as "constantly stressful" both by the respondents and the experts in that field. 46,5\% mentioned interethnic relations as favourable. Implicit tension was mentioned by $40 \%$, and the stressful one was evident for $6 \%$, while $7,5 \%$ were hard to answer. Considering ethnic characteristics leads us to a conclusion that $7,5 \%$ of Tuvinians are

${ }^{1}$ Sociological research of 2013 within the Federal purpose programme "Scientific and pedagogical staff of innovative Russia" for 2009-2013on project "Supraethnic identity: the analysis of state and optimization of regional intercultural cooperation model potential" (agreement 14.B37.21.0511) Sample population is 1000 (Tuva-290, Khakassia-520, Altay-190 pers.); Sociological research 2014 within the President grant on issue "Ethnic and cultural basics for values and identity conflicts in post-Soviet Russia: regional approach" Agreement № 14.124.13.2456-MK. Sample population is 1000 persons (Tuva-290, Khakassia-520, Altay-190 pers.); Sociological research (2016) within the President grant on issue "Russian civil and national identity: new risks and how to overcome the (regional model)" Agreement № MK6746.2015.6. Sample population is 1000 persons (Tuva-290, Khakassia-520, Altay-190 pers.). the most concerned about interethnic cooperation and call them "stressful tension". 54,1\% of Altay people and 42,2\% of Russians mentioned implicit tension. The most positive evaluations were given by the Khakasses, $58,2 \%$ of whom mentioned that these relations are flavourable. Most experts also consider interethnic state in region to be a fairly steadily. ${ }^{17}$ But, some local conflict near the borderlands of Khakassia and Altay took place because of labour migrants from the Middle Asia who were competitors for inhabitants in harvesting. 2014 was rather difficult for the whole country and for the certain region. Also this year was notable for some shifts in people identities' structure and evaluations of interethnic relations. Russian identity, as always, were up-to-date for $30,0 \%$ of respondents that is comparable with 2013 interview results. However, in contrast with $37 \%$ of ethnical Russian who consider themselves to be Russians, only $24,1 \%$ of Khakasses, $22 \%$ of Tuvinians and $10 \%$ of Altay people did so (in contrast with $24-25 \%$ in 2013). So, Russian identity "lost" 2 to $10 \%$. The second position in identities' hierarchy among the region population, like in 2013, took republic identity which was still relevant for Khalkasses $(41,4 \%)$, Tuvinians $(31,2 \%)$ and Altay people $(36,2 \%)$. The settlement identity took the third position $(15,1 \%)$ and was displayed mostly by Russians. Ethnical identity, according to 2014 interview results, moved from the fifth to fourth position $(11,1 \%)$. So, the increasing of ethnical identity followers $(0,5 \%$ more $)$ is quite within the statistic divergence. Also it can be explained not only by its strengthening among region identities, but also weakening of regional and global identities (10\% each). The priority of ethnic identity for inhabitants is within 2013 data. The amount of "I-don'tknow" respondents is equal $2,6 \%$.

When analyzing conflict and tension index we can see strengthening of negative trends in interethnic cooperation in 2014 evaluation. The amount of those who suppose interethnic relations to be favourable, decreased from $46,5 \%$ in 2013 to $38,9 \%$ in 2014 . Implicit tension is considered by almost the same amount (40\% in 2013 , and $39 \%$ in 2014). But stressful tension was noticed by $11,2 \%$ respondents (in 2013 there were only 6\%). Those who "do-not-knowhow-to-describe" interethnic relations were $10,9 \%$ in 2014 and 7,5\% in 2013. This can be an evidence of negative evaluation of interethnic relations in Southern Siberia. About $40 \%$ of the most numerous nations in region consider the tension of interethnic relations to be certain and rather stressful. Stressful tension is mentioned by $13,2 \%$ of ethnically Russian interviewed, while Altay people did not meant any tension (Khakasses- $-6,9 \%$, and Tuvinians 8,3\%). The Khakasses consider interethnic relations to be of implicit tension $(58,6 \%)$, when more than $40 \%$ of Tuva and Altay inhabitants considered them to be quite favourable (36,0 \% of Russians and $24,1 \%$ of Khakasses).

During the difficult 2014 experts' opinions on interethnic cooperation progress were both reasonably negative and rather negative. But the results of 2016 interview did not approve pessimistic moods. The Russian identity $(32,2 \%)$ and the republic one $(23,5 \%)$ still kept their positions. The regional identity was the third $(15,1 \%)$, and the settlement one was the fourth (12\%). Russian identity took a priority for the Russian mostly (43,8\%), and Turkic Siberian ethnoses were in minority (Khakasses $11,3 \%$, Tuvinians $30,9 \%$, and the Altay people $22,4 \%$ ). For most of them republic identity had a great priority (Khakasses-38,8\%, Tuvinians- 33,7\%, Altay people-29,3\%). Ethnic identity, which held the fifth position among all identities in region $(9,8$ $\%$ ), lost its position compared with 2013-2014 interview results (Altay people- $-15,5 \%$, Khakasses $-26,3 \%$, Tuvinians $-9,3 \%$, Russians $-2 \%)$. For $5,6 \%$ of the interviewed cosmopolitan identity is in priority. 
The look on interethnic relations character was also optimistic. In 2016 (the selection and methodology are similar with those in 20132014) $51,7 \%$ of respondents considered interethnic relations to be favourable. In 2014 only $38,9 \%$ were of the same opinion. $35,2 \%$ of the interviewed (in 2014-39\%) mentioned the implicit tension, and the stressful one was discovered by only $2,5 \%$ of respondents. $11,3 \%$ of people interviewed could not give a definite answer. When we take ethnical features of the respondents into account we can see that the whole anxiety level in region is decreasing. But $48,1 \%$ of Khakasses, about $30 \%$ of the Altay people, $27 \%$ of Russians and Tuvinians observed the fact of implicit tension. In other words, there is no straight conjunction between transformations of region inhabitants identities and the dynamics of interethnic relation character, in present days at any rate. So, it is very interesting to observe the reasons for international tensions mentioned by the respondents themselves.

In 2013 one of these reasons was, first of all, high level of migration from abroad and from other regions and territories (17,9\%). Antiimmigrant spirits in 2014 were about $26,6 \%$, with increasing plus $5 \%$ extra in 2016. At the same time, the everyday nationalism was called as the main tension escalation factor by $13,6 \%$ of respondents in 2013 , $29 \%$ in 2014 , and $35 \%$ in 2016 . It's notable that only $10-12 \%$ of the interviewed people considered economic or political problems to be a main factor of interethnic tension escalation.

\section{Results}

So, the results of South Siberia inhabitants' identities structure transformation and its influence over interethnic relation character analysis lead us to conclusion that the revival of regional, settlement, republic and ethnic identities had (and still has) a certain but not the definitive influence over the character and the evaluation of interethnic relations tension. Interethnic relation tension observed nowadays is determined by wide range of factors (economical, political, social ones) and is of rather contradiction then a conflict between traditional and post-traditional outlook systems. This is an evidence of non-classical types of ethnic revival and traditionalism based on reasonable section of individual and group identity. So, all attempts to determine the ethnic self-consciousness growth by the tension strengthening are not right.

\section{Acknowledgments}

None.

\section{Conflicts of interest}

The author declares that there is no conflicts of interest.

\section{References}

1. Gellner E. Nationalism pre-coming. Myths of nation and a class. Nation and Nationalism. 2002;2(1):146-185.
2. Avksentyev VA, Aksyumov BV. Civilization conflict as a shifted identities conflict. Bulletin Stavropol State University. 2006;46(1):5-12.

3. Popov ME. Synopsis of dissertation for candidate of philosophy degree. Stavropol: Identity conflicts in post-traditional Russia; 2001. 58 p.

4. Giddens E. Runaway World. How Globalisation is Reshaping our Lives. Moscow: Ves' Mir; 2004. 120 p.

5. Drobizheva LM. Ethnicity in modern world: new approaches, the old myths, social practices. Bulletin of Sociological Institute. 2010;1:430 442 .

6. Sociological research about "International relations in the Republic of Khakassia in evaluations and opinions of mass consciousness" ordered by Ministry of education and science of the Republic of Khakassia. Vyborochnaya sovokupnost'. The aggregate sample-300 people. 2011.

7. Malahov V. Modest racism charm. Moscow: Modest Kolerov i Dom intellektual'noy knigi; 2001. 176 p.

8. Vishnevskii AG. Sickle and rouble: conservative modernization in the USSR. Moscow: OGI; 1998. 429 p.

9. Kotozhekov GG. People of Khakassia about their life: the results of sociological research on the issue "State of international relations in the Republic of Khakassia in evaluations and opinions of mass consciousness. Abakan: KHRIPKiPRO Rosa; 1994. 72 p.

10. Anzhiganova LV, Kotozhekov GG. International relations in Khakassia: the results of sociological research on the issue "State of international relations in the Republic of Khakassia in evaluations and opinions of mass consciousness". Abakan: KSU; 1997; 51 p.

11. Ibragimova VG. Religious and moral consciousness of the Republic of Khakassia population: problems and perspectives of development. Abakan, NSU; 2007. 208 p.

12. Aksutin Yu M. The influence of post-Soviet Russia region inhabitants' identity structure transformations over interethnic relationship (on an example of Southern Siberia). New Research of Tuva. 2016;2:5-12.

13. Popkov Yu V, Kostiuk VG, Tuguzhekova VN. Siberian ethnoses in the conditions of modern reformations (sociological examination). Novosibirsk, NSU; 2003. 128 p.

14. Anzhiganov LV. Ethnic and social situation in Khakassia in evaluations and opinions of mass consciousness. Abakan: KSU; 2006. 105 p.

15. Aksutin Yu M, Nikitin AP, Tyshta Ye V. Supra-ethnic identity: the analysis and evaluation of potential optimization of the regional model of intercultural interaction. Abakan: Servisnyy punkt; 2013. 152 p.

16. Tyshta EV. International relation in Khakassia: historiographic review. Moscow: Ethnic and social problems in Siberia regions. 2013.80 p.

17. Popkov Yu V, Persidskaya OA. The comparative research of ethnic and social processes and ethnic and social policy in Siberia regions. New researches of Tuva. 2014;4:25-39. 